\title{
Family Life
}

\section{and}

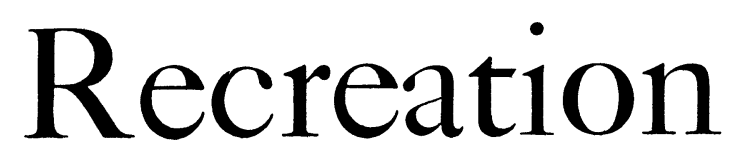

Circular No. 383

\section{COOPERATIVE EXTENSION WORK} in

AGRICULTURE AND HOME FCONOMICS

State of Oklahoma

SHAWNEE BROWN, Director, Stillwater

OKLAIIIOHA

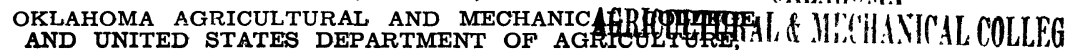
AND UNITED STATES DEPARTMENT OF AGRtE

Distributed in Furtherance of Acts of Congress of May 8 and June $30,191 . \mathbf{R} \mathbf{Y}$ 


\section{Family Life and Recreation}

FLOYE FLOOD

Extension Specialist in Child Development and FamiYy Life

\section{OKLAHOMA FARM FAMILIES NEED TO PLAY TOGETHER}

RECREATION AIDS THE WAR EFFORT. It helps to relax tense nerves and muscles. It refreshes tired bodies and minds. It makes work easier and increases efficiency.

RECREATION BUILDS MORALE. It helps us to forget our fears and worries, and it makes life happier. It brings those at home together, and increases the feeling of security.

RECREATION PROMOTES BETTER FAMILY RELATIONSHIPS. It helps us to work together and to understand each other. It gives parents an opportunity to cultivate life-long interests, attitudes, and ideals in their children.

Fun with the family and neighbors is something you and your children will always remember. It costs nothing but your time, thought, and good nature.

This leaflet presents a few suggestions for having fun. No idea is of use to you until you have put something of yourself into it, and put it to work.

Try some of these suggestions. Improve on them. And see what fun you have!

\section{Family Fun and Family Relationships}

Every man, woman and child, old and young, needs three kinds of recreation: (1) family recreation with those at home; (2) neighborhood recreation with others of like ages and interests; and (3) individual recreation with oneself.

Now that families must stay at home more and more, you will want to learn all you can about home play.

In planning family fun consider all ages. Use activities which the entire family will enjoy. Dropping beans into a milk bottle, piling matches across the top of a glass jar, tossing washers into a muffin tin--these are all simple, but they are fun and everybody in the family can play them together. You stop playing not because you grow old; you grow old because you stop playing.

Consider the cost. Simple, inexpensive, stay-at-home recreation is possible for every family in wartime. Use what you have at hand to make games. The home is full of play equipment if you only look around and see the possibilities. Hide the Thimble, Hul Gul, Button-Button, and Spin the Pan are old time favorites played with household articles. For a 
game of skill, try tossing cards from a distance of five feet into a wastepaper basket. It's a good test of muscle control, and everyone young and old will enjoy it. Picking up all those cards that missed the basket is good exercise too!

Ask the children to help with the family fun. Let them make up new rules for old games. Sometimes they learn games at school and are very happy to teach them to the family.

What games did you enjoy when you were a child? Why not revive them? Your children will enjoy the songs and stories that you remember too. They love to laugh at funny things that really happened and to hear about true adventures.

Recreation is limited only by your imagination. Can you use your imagination to produce fun for the family?

TIME OUT FOR FUN. In busy wartime it is necessary to plan your work so you will have time to play together, for it is as important to play as it is to eat and sleep. War work comes first, but all work and no play is weakening. Has your family planned together to finish work early enough to have some time for family fun?

Some family recreation can be carried on as work is being done. Singing while washing dishes or cleaning house is fun and makes the task seem less like work. Even a singing game is fun if used occasionally. Do you remember:

\section{"This is the way we make our bed, Make our bed, make our bed. This is the way we make our bed so early in the morning."}

\section{Family Celebrations and Traditions}

Continue to have family celebrations in wartime. They are fun; they are special; they are interesting; and they create unity within the group. Even though all family members cannot be together it is better to be happy with those at home than to sit and worry and grieve.

Don't forget special celebrations! They need not take time and money from the war effort. Meals can be rich with laughter at no cost except a little thought and effort. Try serving the meals in different places occasionally as a surprise.

Holidays can be turned into parties. Let the children make simple place cards and table decorations. Teach them holiday traditions. Tell stories and sing songs. Every now and then have a special celebration just because you want to -it's fun. 
Consider every member of the family. No one should be overworked, overexcited, or overlooked. Share the fun and share the work. See that no one person, especially mother, is overworked.

The younger the child, the more simple his part in the celebration should be. His routine should go on as usual with regular meals and sleep. But, even a four- or five-year-old can help plan the celebration, and he can help select and make decorations if assisted.

Older family members can help too. They can have a part in planning for the occasion and can take an interest in new ideas about the celebration. They can teach traditions and encourage the children to tell stories and sing songs learned at school. They can keep regular hours and habits.

\section{Neighborhood Recreation}

In wartime more than ever before, neighborhood recreation should replace amusements that require travel. It brings people of like ages together for pleasure and association. Boys and girls especially need the companionship of others their own age. In fact, all family members need to keep in touch with people outside their home group.

As neighbors come together again and again for good times, they build a feeling of general friendliness and good will which can be valuable long after this emergency has passed. It encourages a spirit of cooperation. People who play together understand each other better and can work and live happier in the neighborhood.

To be effective neighborhood recreation should be organized. The ideal plan is to ask all organizations to form one sponsoring committee to take the lead and plan the responsibilities which must be met.

Neighborhood Recreation Develops Leadership. No one person can conduct all recreational activities. But, in every neighborhood there are those who can direct singing, or marching, or crafts, or games, and the like. Encourage others to share in the leadership. Old folk, young folk-all can help and all are needed. bors.

Here are some suggestions. Try these with a few neigh-

1. Plan your entertainment.*

2. Be on time and have everything ready.

\footnotetext{
* See page 9 of Recreation Manual for Home Demonstration Clubs. Extension Circular 358 .
} 
3. Ask certain friends ahead of time to assist you. This is good leadership training for them.

4. Remember that the games are for fun. So, help the group enjoy them. Stop a game before players tire of it.

5. Give a few simple directions at the beginning. $\overline{A \bar{d}} \mathrm{~d}$ other instructions as needed.

In planning a neighborhood party it is wise to have a "mixer" to give folks a chance to get acquainted and to give them something to do until everyone has arrived. The "Everybody Play Hour" should include both active and quiet games. People like to feel relaxed or "re-created" when they leave for home, so they should never be dismissed abruptly after an active game. Refreshments or a period of singing may conclude the evening's fun. The program for one meeting might be as follows:
A "Mixer"** Human Bingo
Begin when persons arrive. Let the first one or two give out necessary material.
A "Stretcher"**
I Say Stand
Use this any time during the program when you wish to relax the group for two or three minutes.

Everybody Play Hour**

Jump the Shot
Clothes Pin Relay
Buzz
Oh Susanna

Refreshments and/or group singing

Another evening might be spent by using various games that require simple equipment. During the "Everybody Play Hour" the guests may play whatever games they like. Suggested games with equipment: mass deck tennis; 105; washer pitch; bean bag toss; disco; ten pins; card games; dominoes.

Does Your NeIghborhood ReCreation Include These:

Parties for boys and girls with some young, responsible adult in charge?

Parties for children?

Family parties to which all family members go?

Equipment which can be used by all?

Are all families in the neighborhood invited and made to feel welcome? Have you done your share in carrying on neighborhood recreation? 


\section{Individual Recreation}

Everyone needs some time to do exactly as he pleases-to read, to knit, to make scrapbooks, to hike-to entertain himself. It can be fun! It can help you forget all else for the time being. It can keep you from being lonely if you really become interested in what you are doing.

Individual recreation may be carried on in groups as well as alone. For instance several women and girls may enjoy coming together to knit, or to do other individual tasks.

What kind of individual recreation do you use?

HobBies. A hobby is something that you do not have to do, but something you genuinely want to do. It can furnish real relief from worry, disappointment, grief, and fear. It can help you become a more interesting person because it gives you something to talk about and to do.

Family hobbies strengthen family ties. Interests are shared, help given, and there is a feeling of togetherness.

Music is a good family hobby. Each member can find some part that is interesting to him, and at the same time he will be making some contribution to the group. No member need feel left out because of lack of special ability, for a music hobby does not mean just playing some instrument. It can include making up words for songs, singing or playing together, listening to radio programs, or reading about music or musicians. The interest can shift from time to time and thus keep the hobby alive and on going.

Families who have good times with a hobby have less of a problem with commercial entertainments.

A few suggestions for family hobbies:

$\begin{array}{llll}\text { Flowers } & \text { Puzzles } & \text { Rug making } & \text { Flags } \\ \text { Leaves } & \text { Stories } & \text { Dolls } & \text { Puppets } \\ \text { Badges } & \text { Coins } & \text { Buttons } & \text { Carving }\end{array}$

Provide space in your home, and time in your life for individual recreation.

\section{Games}

\section{MIXERS:*}

Human Bingo-As guests arrive have them write their name on two slips of paper. One name is pinned on, and the other dropped into a box Each person is given a sheet of paper divided into 16 squares, and is told tc get the signature of someone present in each square. The leader draws names from the box. When a player's name is called he stands and turns

* Other good "mixers" and "stretchers" may be found in Recreation Manual; in Handbook for Recreation Leaders; and in Handy I, Kit G. These references are listed on page 8 of this bulletin. 
slowly around. Every player with the name on his sheet checks it. When a player gets four checks in a row, horizontally, vertically, or diagonally, he calls "Bingo." A small prize or piece of candy is his reward. Continue until four or five players "Bingo."

Neighbors-Formation-single circle with one person in the center who has the privilege of pointing unexpectedly to anyone in the circle and asking the name of either his right or left neighbor, or both. If he cannot answer before the one in the center counts ten, he must change places and remain there until he catches someone who does not know the names of his neighbors. Neighbors must change often. This is done through the crder "Fruit Basket," which means that everyone must find a new set of neighbors. Any one found standing next to an old neighbor may be called to the center of the circle as punishment.

\section{STRETCHERS: (See footnote on page 6) :}

"I Say Stand"-The leader shouts, "I say stand," at which command all players must stand. "I say stoop," and all players must stoop. The orders are given in rapid succession. The catch comes in the fact that the leader does not always fit his action to his command. For instance, he may say, "I say stand," and at the same time assume the stooping position. Any player who makes a mistake is out. No order should be obeyed unless the leader first says "I say."

Puppies Fly-The group may be seated or standing in any formation. The leader says "Robins fly," and raises his arms up and down in flying motion. The group does the same. This is repeated, using the name of anything that flies. If the leader names something that does not fly, as, for example "Elephants fly" or "Puppies fly," no one should fly. The leader "flies" whether right or not. Anyone who makes a mistake turns his face to the wall.

\section{Everybody Play Hour:}

The games that are starred $\left(^{*}\right)$ are readily adapted to a group of all ages so that any children present may easily take part.

Buzz-Five to thirty players. One of the players starts the game bv saying, "One." The others, in turn, say, "Two," "Three," "Four," "Five," and "Six." But when "Seven" is reached that player must say, "Buzz." The counting goes on, but each time there is a multiple of seven or any number with seven in it the player must substitute "Buzz" for the number. Thus 14, 21, 28, and others that are multiples, and 17, 27, 37, and others containing the number seven must not be repeated. "Buzz" is repeated in their stead. Penalty for infraction of this rule is dropping out of the game or paying a forfeit.

Variations-Players may call the "Buzz" number, making it 3, or 5, or 8. In this case the "Buzz" would come on the number called and on its multiples.

*Laugh-Players are seated in a circle. The first player starts by saying, "Ha." The second player says, "Ha, Ha." The third says, "Ha, Ha, Ha." And so it goes around the circle with each player adding another "Ha." In each of case "Ha's" must be pronounced solemnly, or pain of dismissal from the circle. The chances are, however, that it will not get around the circle before the entire circle is responding with gales of laughter.

* Jump the Shot-A stuffed sack or sponge is tied to the end of a long heavy string or rope. The players form a circle whose radius will be just a little less than the length of the string. A player in the center swings the 
sack around so that each man in the circle has to jump to keep it from hitting him on the feet. Any player who is hit must take the place of the man at the center.

Variation-Use a fishing pole instead of the string and sack.

Clothespin Relay-Form relay teams of not more than 10 players each. The captain of each team holds 15 clothespins. At the signal to start, he puts all of them on the floor in front of player next to him. Each player must have all the clothespins in his hands before he can lay them in front of his neighbor. The side that can first pass them down its line and back to its leader wins.

Oh Susanna*-Formation: A large circle facing center, ladies on men's right, and extra men (or ladies) in the center.

\section{WORDS AND ACTION}

1. I come from Alabama with a banjo on my knee. Ladies take 4 steps into the center and 4 steps back.

2. I'm going to Louisiana my true love for to see. Men take 4 steps into the center and 4 steps back.

3. It rained all night the day I left;

The weather it was dry.

The sun so hot I froze to death, Susanna, don't you cry.

Partners face each other and do the grand right and left. The extras can get in the grand right and left and can try to take someone's partner on the promenade.

4. Chorus:

Oh! Susanna, don't you cry for me.

I come from Alabama with my banjo on my knee.

Everyone takes a partner on the word "Oh" and promenades (counter-clockwise).

(Repeat from beginning.)

\section{SOURCES OF INFORMATION}

Recreation Manual for Home Demonstration Clubs-Extension Circular 358, Extension Division, Stillwater, Oklahoma.

Handbook for Recreation Leaders-Ella Gardner. U. S. Dept. of Labor, 231, Superintendent of Documents, Washington, D. C.

Handy I, Kits A through J. Handy II, Kits L through V. Cooperative Recreation Service, Delaware, Ohio.

The National Recreation Association, 315 Fourth Avenue, New York, New York publishes many leaflets on family and neighborhood recreation. Write for complete list of publications.

* Other musical games are given in Recreational Manual. 